\title{
Reseña de Sánchez Montes, Francisco, El viaje de Felipe IV a Andalucía en 1624. Tiempo de recursos y consolidación de lealtades, Granada, Editorial Universidad de Granada, 2018, 383 pp., ISBN 978-84-338-6274-7
}

\section{Ofelia Rey Castelao}

ORCID: http://orcid.org/0000-0002-9720-8486

Universidad de Santiago de Compostela

ESPAÑA

ofelia.rey@usc.es

[Hipogrifo, (issn: 2328-1308), 7.1, 2019, pp. 739-742]

Recibido: 13-03-2019/ Aceptado: 27-03-2019

DOI: http://dx.doi.org/10.13035/H.2019.07.01.56

La proliferación de estudios sobre viajes que vivimos en los últimos años constituye solo una novedad relativa, por cuanto es un género que siempre ha interesado, quizá no tanto a los historiadores como a los historiadores del arte y de la literatura, ya que en nuestro campo los relatos de viajes se han considerado más como una fuente o un capítulo complementario que en sí mismos, con algunas salvedades, claro está. El libro que comentamos está en este último grupo. No en vano el largo periplo de Felipe IV por Andalucía no fue una visita de paseo ni estuvo destinado al conocimiento de un territorio, sino que constituyó una acción política en toda regla, con objetivos definidos dentro de los intereses que marcaban el reinado recién empezado de ese joven rey. Es el análisis de esta importante dimensión lo que aborda Francisco Sánchez Montes apoyándose en un amplísimo bagaje de lecturas y de fuentes documentales.

El protagonismo del viaje y del libro que comentamos no recae solo en el monarca, sino en el conde-duque de Olivares, dada su relevancia política en la fase inicial del reinado de Felipe IV y su capacidad de movilización para organizar aquella fantástica expedición. Además, y al mismo tiempo, estamos ante un relato coral en el que aparece un sinfín de nombres relevantes: nobles de primera fila - destacando el octavo duque de Medina Sidonia, don Manuel Alonso Pérez de Guzmán y Silva, y el quinto marqués de El Carpio-, testigos de excepción como Francisco de Quevedo y personajes secundarios - miembros de las oligarquías 
locales, del clero-, que fueron más actores que testigos del transcurrir del séquito real por tierras castellanas, primero, y luego por caminos andaluces, ya que de su actitud ante la comitiva dependía gran parte del éxito o del fracaso del viaje iniciado el 8 de febrero de 1624, hasta el 18 de abril.

La obra de Francisco Sánchez Montes no se limita a relatar y a analizar el viaje. Antes de esto se dedican más de ciento treinta páginas a hacer un panorama reflexivo de los comienzos del reinado de Felipe IV y del estado de la monarquía y de sus reinos en esos momentos, páginas esenciales para explicar las causas de la visita a las tierras meridionales. El reformismo con el que Olivares inició su gobierno y los apuros financieros heredados de Felipe III aparecen así como antesala para estudiar un periplo que tenía como objetivo convencer a las ciudades y a las oligarquías andaluzas para que colaborasen en la tarea de reflotar a una hacienda en quiebra y a poner las bases de una recuperación mediante las reformas ideadas por Olivares. Para el rey y, sobre todo, para su valido, era esencial conseguir la adhesión de la nobleza andaluza al sistema, y para el poderoso grupo nobiliario andaluz, el viaje iba a ser una ocasión para reposicionarse ante el poder de un nuevo monarca, entendiéndose para ello con el propio Olivares. Si se eligió Andalucía fue porque se trataba de uno de los territorios que disponía de mayor riqueza, de modo que se esperaba que las jornadas fueran una oportunidad para explorar «unas tierras susceptibles de contribuir más en beneficio de la Corona, frente al agotamiento de una Castilla interior exhausta», así lo sintetiza el autor en las páginas 188-189.

El resultado del viaje a Andalucía no respondió a los objetivos económicos que se pretendían, como revela el análisis que el autor hace de la reacción y respuesta de cada ciudad visitada o de los miembros de las oligarquías, poco colaboradores unas y otros con el rey y con Olivares. Más útil fue desde el punto de vista militar, ya que la visita resultó fundamental para reforzar el control del litoral sur peninsular, clave en el cuadro de la política internacional de aquellos años, no solo desde el punto de vista de la defensa - vigilancia del Estrecho- sino incluso de una recuperada idea de expansión en África septentrional. Por supuesto, la presencia y ocasión de contemplación del joven rey acompañado por su numeroso y vistoso séquito sirvieron para reforzar la imagen de la monarquía, dada la rareza de los desplazamientos de los reyes más allá de la Corte y de los sitios reales. Pero, sin duda, si hubo alguien que se benefició de esto, tanto o más que el propio Felipe IV, fue el conde-duque de Olivares, que aprovechó la organización del viaje y todas las ocasiones políticas y sociales a las que este dio lugar para mostrar su propia imagen de gobernante, su capacidad de gestión y de gobierno, y su indudable protagonismo en la fase inicial de su valimiento.

Francisco Sánchez Montes insiste a lo largo del libro en que el viaje no fue una visita de diversión y de lucimiento. No hay la menor duda y así lo demuestra con total solvencia: las fuentes y datos que ha recopilado y contrastado revelan una intencionalidad política de envergadura; el rosario de resistencias opuestas por diversos grupos de interés en el poder local y regional a las pretensiones de los 
visitantes corroboran la relevancia de la dimensión política, lo que incluye la faceta de representación y de símbolo y el efecto que a ambos se les debe otorgar.

Pero eso no resta importancia, al contrario, a la parte organizativa del viaje. Consideramos que son de gran interés las páginas dedicadas a la comitiva y a sus componentes, a los caminos y a sus obstáculos, a las dificultades logísticas y a los medios materiales requeridos para aspectos fundamentales que iban desde la alimentación al alojamiento, pasando por el transporte y sus problemas. Se trataba de una expedición numerosa y costosa que se desarrolló en un espacio anfractuoso desde Madrid hasta llegar a la costa - primero la atlántica, luego la mediterránea-, de modo que su relato nos da una visión diferente de la existencia cotidiana de Felipe IV. Por otra parte, las páginas dedicadas a los agasajos de los que el rey fue objeto tienen un espacio importante en el libro, no solo en su descripción, sino en lo que tenían de protocolario y simbólico, tanto por parte de quienes los hacían, como por quienes participaban o los contemplaban, sectores populares incluidos, no en vano eran los observadores silenciosos de tan extraordinaria ocasión. La culminación se alcanzó en los famosos días del rey en el coto de Doñana, donde su anfitrión, don Manuel Alonso Pérez de Guzmán, VIII duque de Medina Sidonia, desplegó toda su riqueza y lucimiento «en la más fastuosa recepción hecha a un monarca», p. 25; el relato de la estancia y de las fiestas, comidas y paseos, de los que ha quedado una abundante documentación, permite ver la firme adhesión de la casa ducal a la monarquía, pero también el poder del que la casa disponía en el entorno sevillano y el lado atlántico de Andalucía y su capacidad de control sobre sus propias redes sociales.

Como es lógico, las fuentes fundamentales empleadas por el autor son las generadas por el propio viaje, que se encuentran en los grandes archivos de la monarquía hispánica, el de Simancas en especial. También lo son los varios relatos que se hicieron tanto por agentes del propio séquito, como en los lugares donde Felipe IV fue recibido. La localización de esos textos se ha hecho en una amplia variedad de bibliotecas, lo que revela el interés de Sánchez Montes en no dejar ninguna faceta de lado y en aportar todos los puntos de vista de un hecho itinerante que se pensó y diseñó para ser observado, admirado y, finalmente, narrado. Algunos de estos relatos fueron llevados a la imprenta por entonces, lo que en sí mismo tiene un alto valor simbólico, ya que sus autores y comitentes no solo pretendían dar cuenta de su participación y/o contemplación, y congraciarse con quien fuera conveniente, sino dejar memoria de un hecho que era extraordinario fuera de la Corte. De igual e incluso mayor importancia es la abundante documentación local consultada en los archivos municipales de las ciudades por donde el séquito pasó - Córdoba, Granada, Jaén, Málaga, Motril, Medina Sidonia, incluso de la villa de Madrid-, en los correspondientes a instituciones de algunas de esas ciudades abadía del Sacromonte, Alhambra y Generalife - y de la nobleza implicada en el periplo, en especial la casa de Medina Sidonia, cuyo archivo es fundamental en este libro. El libro finaliza con un amplio apéndice documental, nutrido con piezas de la Real Academia de la Historia, de la Biblioteca Nacional o del Archivo General de Simancas, que consideramos de gran utilidad por su buena selección. 
Terminamos elogiando el estilo de la obra, ágil y de fácil lectura, lo que facilitará su acceso por parte de un público mucho más amplio que el académico. En muchos episodios del viaje y en otros tantos fragmentos del libro se exponen ricos aspectos y detalles de la vida cotidiana, desde lo más básico a lo más extraordinario que se podía tener o disfrutar por parte de las clases poderosas de entonces, lo que sin duda contribuye a suavizar el contenido y a añadir atractivo al texto. Algunas escogidas imágenes sirven para presentar y apoyar diversos aspectos del viaje - planos de núcleos visitados, mapas del itinerario seguido, portadas impresos escritos ad hoc, etc. - , colaborando para que, desde las facilidades y comodidades de los viajeros del siglo XXI, podamos imaginar las dificultades vividas por un rey para hacer sus Jornadas de Andalucía en el final del invierno y comienzos de la primavera de 1624. 